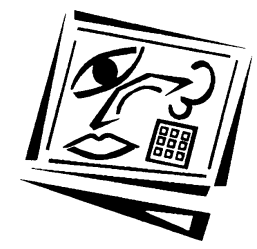

\title{
Using blended creative teaching: Improving a teacher education course on designing materials for young children
}

\author{
Shi-Jer Lou, Nai-Ci Chen \\ National Pingtung University of Science and Technology \\ Huei-Yin Tsai \\ National Kaohsiung Normal University \\ Kuo-Hung Tseng \\ Meiho University \\ Ru-Chu Shih \\ National Pingtung University of Science and Technology
}

\begin{abstract}
This study combined traditional classroom teaching methods and blogs with blended creative teaching as a new teaching method for the course Design and Applications of Teaching Aids for Young Children. It aimed to improve the shortcomings of the traditional teaching approach by incorporating the Asking, Thinking, Doing, and Evaluation (ATDE) teaching model and encouraging interactions between teacher and students. The purpose of this study was to examine the effectiveness of using blogs in blended creative teaching while also exploring the ideal blended creative teaching model, work completion rates, patent applications (as the teaching outcome), and learning attitudes of students. The research subjects were 46 second year students from the department of early childhood education in a vocational high school. Data were collected from qualitative teaching materials, teaching logs, learning logs, blog applications, and quantitative survey questionnaire. The results showed that the ideal blended creative teaching model can be implemented over six stages. Additionally, creative techniques can help teachers generate ideas on teaching material design and facilitate patent applications. Furthermore, the results of the survey indicate that students possessed positive feedback and affirmation toward the blended creative teaching model. Finally, blog teaching can help enhance interactions between teachers and students and among peers, thus improving the effectiveness of learning.
\end{abstract}

\section{Introduction}

\section{Research background and motives}

The arrival of an innovative and technology-driven teaching era has changed the way teachers and students interact, and now 'one-way' teaching methods as used in earlier times cannot provide sufficiently well for students' learning. Nowadays, the use of the Internet, digitalisation, and virtualisation enables the integration of technology and educational resources to help form a learner-oriented teaching environment. Educational reforms are emerging worldwide to enhance learning effectiveness. However, incorporating information and communication technology (ICT) 
applications into teaching does not guarantee teaching effectiveness and quality. The characteristics and readiness of learners, curriculum, and network environments must also be considered (Chen, 2004). Blended teaching combines e-learning and traditional teaching, namely virtual curriculum and classroom curriculum, and focuses on teacher guidance and student autonomy (Yen, Lo \& Wang, 2009). Learners benefit from the convenience and richness of online learning. Apart from the advantages in learning effectiveness, time utilisation, and budgets, online learning provides a natural and flexible means of gaining knowledge (Singh, 2003; Bersin, 2004).

In terms of ICT applications in education, using simple blogs can ease technical entry barriers and help in countering time and space limitations. As Bill Gates pointed out, blogs may be rated as the fourth world-changing "killer application", following emails, BBS, and instant messages (Shih, 2005). Given their ready availability and ease of use, this study chose to use blogs as the major teaching platform. According to the Two Competence Indicators or Benchmarks for Grade 1-9 Curriculum Guidelines, "appreciation, expression, and innovation" and "independent thinking and problem solving," are important focuses in the current education agenda (Taiwan Elementary and Secondary Educator Community, 2008; Ke, 2004). The development of these abilities requires the application of creative teaching. Creative teaching aims to empower teachers and learners to break through fixed moulds and establish innovative cognitive structures in order to transform concepts and ideas into actions (Ke, 2004).

Therefore, this study seeks to incorporate the spirit and techniques of both creative teaching and blended teaching, including the use of traditional methods and blogs. Students were empowered to exercise their creativity in designing teaching materials. A variety of teaching techniques and strategies were applied to guide students through problem solving in teaching material design, new idea generation and implementation. It was hoped that blended teaching could improve learning effectiveness and achieve teaching goals. Based on the above, this paper sets out the following research purposes:

1. To establish the blended creative teaching model;

2. To examine the learning effectiveness of the blended creative teaching model;

3. To investigate students' learning attitudes toward the blended creative teaching model.

\section{Literature review}

\section{Blended teaching and learning}

Blogging as a medium that allows bloggers to record everything and anything they are interested in was first proposed by Jorn Barger in 1997 (Liu, 2005; Shih, 2010). Blogs can be managed by individuals or groups. Text, photos and video clips can be posted at the individual's discretion. Bloggers can take notes online, leave messages, and share their stories and thoughts; thus, blogs may be like diaries on the Internet. Blogging is known for the following features: (1) low technical entry barriers, (2) high autonomy, (3) cross-platform or platform independent interactions, (4) real-time publications and updates, (5) a diversity of applications, and (6) ease of use (Khine, 2007; Shen, 2007; Brady, 2007). In education, blogs may become a personalised and user-friendly teaching-aid medium. For instance, a class blog enables students and teacher to share their ideas; become regarded as a collaborative discussion space; and a 
learner blog may enable students to create their own personal online space, which can encourage them to write about things that interest them most, and post comments on other's blogs (Ozkan, 2011). Many studies also revealed that blogs enable learners to respond and read each others' comments in a dynamic and interactive manner. Blogging with peer assessment and peer feedback can help students reflect and focus upon professional activities and record evidence within a supportive peer assisted learning environment, thus improving their learning effectiveness (Chen et al, 2011; Liu \& Chang, 2010; Lou, Wu, Shih \& Tseng, 2010; Tan, Ladyshewsky \& Gardner, 2010).

Blended teaching models aim to bridge two contrasting perspectives on learning methods, namely, teacher-led classroom teaching versus learner-oriented online learning. In fact, different combinations of these perspectives can be utilised. It is hoped that the advantages of using different learning techniques will enhance the quality of teacher-learner interactions and reduce dropout rates (Wang \& Su, 2005). Blended learning combines e-learning and classroom learning characteristics and the benefits, as summarised in Table 1. By integrating the particular advantages of classroom teaching and e-learning, students are helped to adjust their learning progress, reinforce what they have learned, and personalise their learning process. The blended teaching model developed in this paper realise these goals by integrating blog-learning and face to face learning characteristics and benefits.

Table 1: Characteristics and benefits of blended teaching for teachers and learners

\begin{tabular}{|c|c|c|c|}
\hline \multicolumn{2}{|c|}{ E-learning } & \multicolumn{2}{|c|}{ Classroom learning } \\
\hline Teachers & Learners & Teachers & Learners \\
\hline $\begin{array}{l}\text { Decisions on learning } \\
\text { objectives and control } \\
\text { over progress } \\
\text { Teaching of learning } \\
\text { strategies } \\
\text { Leading discussions } \\
\text { and activities } \\
\text { Answering questions } \\
\text { from learners } \\
\text { Leading simultaneous } \\
\text { learning activities } \\
\text { Sending messages to } \\
\text { learners } \\
\text { Uploading teaching } \\
\text { materials } \\
\text { Production of digital } \\
\text { learning result evalu- } \\
\text { ations and self assess- } \\
\text { ment worksheets }\end{array}$ & $\begin{array}{l}\text { Self learning } \\
\text { Self assessments } \\
\text { Participation in discu- } \\
\text { ssions and questions } \\
\text { Simultaneous learning } \\
\text { Utilising supporting } \\
\text { resources } \\
\text { Sharing learning } \\
\text { results }\end{array}$ & $\begin{array}{l}\text { Preparations of } \\
\text { teaching materials } \\
\text { Lecturing } \\
\text { Arrangement of } \\
\text { classroom activities } \\
\text { Encouraging interac- } \\
\text { tions between learners } \\
\text { Encouraging } \\
\text { experience sharing } \\
\text { Answering questions } \\
\text { from learners }\end{array}$ & $\begin{array}{l}\text { Listening } \\
\text { Participation in } \\
\text { classroom activities } \\
\text { Interpersonal } \\
\text { interactions } \\
\text { Experience sharing } \\
\text { Sharing learning } \\
\text { results }\end{array}$ \\
\hline
\end{tabular}

Source: Yu (2008, p.39)

In summary, blended teaching can leverage the advantages of both face to face and digital teaching McCarthy, 2010; Lou et al, 2011; Shih, 2011). Blogs provide an easy to access platform for both teachers and students while resolving the time and space restrictions of bricks and mortar classrooms. Blogging instruction should be able to 
effectively enhance interaction between learners, instructors, and course content. Additionally, many studies show that blended teaching with blogging can provide a diversified and interesting learning environment for learners and instructors as well as for improving the effects of students' collaboration and interaction (Lou at al, 2010; Shih, 2010; Wang, 2010).

\section{Concepts and strategies of creative teaching}

Creative teaching refers to the application of original teaching techniques to the systematic seeking of resources and the expression of creativity in teaching scenarios (Wu, 2003; Lin, 2002). Creative teaching applies flexible and appropriate techniques so that classes are fun and interesting. Its ultimate purpose is to encourage students to develop their creative skills. In creative teaching, teachers are the inspirers, navigators, and sharers of knowledge. Based on creative science and creative psychology, creative teaching is an open and inspiring approach for encouraging students to explore and innovate in order to develop their ability to create and think.

However, since there are various creative teaching strategies, teachers should be able to adopt the most appropriate strategies based on subject matter, targets, and teaching resources. This paper applied the Asking, Thinking, Doing, and Evaluation (ATDE) teaching model as the student-teacher interaction guidelines to the course titled Design and Application of Teaching Aids for Young Children. Additionally, the "12 Secrets to Creativity", "SCAMPER", and patenting techniques were used to guide students to form new concepts and ideas as well as reconstruct their teaching materials. Through these strategies, we hope that the reconstructed teaching materials will be novel, progressive, and practical for the industry.

Below are detailed explanations of creative teaching strategies. The ATDE teaching model consists of the following four elements (Chen, 1990):

1. Asking: Teachers design question scenarios by providing divergent and convergent questions to guide students through the thinking process.

2. Thinking: Teachers encourage students to freely associate on the given questions. Students take their time to seek creative solutions.

3. Doing: Teachers use various methods to allow students to seek solutions in activities and take appropriate actions.

4. Evaluating: Teachers and students work together on the criteria definitions and assessment process. They learn to respect each other. Creative thinking is brought into their practices.

The Checklist Technique is a method used to find clues and establish concepts by compiling everything related to a given problem or subject into a list (Kuo, 1994). Specifically, checklist is a summary of problems or directives for reforms. Checklist intends to cover all the issues and identify opportunities of multiple facets. Eberle $(1971 ; 1982)$ referred to the checklist developed by Osborn to develop another checklist technique known as seven directions for improvements or changes: SCAMPER, which is a technique to help generate new ideas. Chen (2002) proposed seven Chinese characters, as described in Table 2.

Based on the creative matrix, the "12 Secrets to Creativity" can be summarised as follows: (1) addition, augmentation and increase (add something); (2) elimination and reduction (deduct something); (3) expansion and extension (expand something); (4) 
compression (compress something); (5) improvement (change something); (6) alternation and rearrangements (alter something); (7) movement and push-around (move something); (8) imitation (learning something); (9) replacement (replace something); (10) connection (link something); (11) reversals (reverse something); and 12) regulations and boundaries (define something).

Table 2: Seven Chinese characters (Chen, 2002)

\begin{tabular}{|c|c|c|}
\hline 伐 & Replace & Whether the original object can be replaced with another object. \\
\hline 結 & Combination & $\begin{array}{l}\text { Whether the original object can be combined with another object into } \\
\text { single object. }\end{array}$ \\
\hline 應 & Addition & Whether the original object be added to something else. \\
\hline 改 & Change & $\begin{array}{l}\text { Whether some characteristics of the original object, such as meaning } \\
\text { color, sound, and form, can be changed. }\end{array}$ \\
\hline 他 & Alternatives & Any other, non-conventional utilisations. \\
\hline 去 & Removed & Whether the original object can be condensed and refined. \\
\hline 重 & Re-arranged & Whether a rearrangement of the original sequence is possible. \\
\hline
\end{tabular}

The six factors regarding patent rights are methods, functions, shapes, structures or installations, patterns and colors (Chou, 2008). These directions provide a guideline for the design and production of creative teaching materials. According to Article 21, Article 93, and Article 109 of the Patent Laws in Taiwan, inventions are the creation of technological ideas based on the laws of nature. New utility model patents are technological ideas of shapes, structures or installations based on the laws of nature. Design patents are creations of visual appeals based on shapes, patterns, colors or any combinations thereof. Associated design patents are similar creations following new designs from the same individuals. Apart from meeting the above basic requirements, new designs and associated design patents should be applicable, novel, and progressive. Before becoming involved in patents and inventions, individuals are advised to be familiar with the patent laws and gather information in advance to ensure the best results with minimum effort.

According to the advantages of blended teaching, blogging, ATDE model, " 12 Secrets to Creativity", and SCAMPER, this paper integrates the advantages mentioned above into creative teaching strategies in order to create a sound and open learning environment that allows students to gather information regarding the teaching aids they are interested in and to engage in discussions on the basis of their existing knowledge and background. The purpose was to encourage students to think creatively to produce multi-functional and educational teaching aids suitable for young children. Problems were identified and resolved using a scientific approach, with the ultimate goal of producing creative teaching aids.

\section{Research method}

\section{Subjects}

The subjects were 46 students in their second year in the Department of Early Childhood Education from a vocational school in Pingtung County. Students were 
divided into groups of four or five. The instructor was both the class supervisor and the teacher for the course Design and Production of Teaching Aids for Young Children. Previously, most of the students were taught only through traditional classroom teaching. The evaluation focused on the individuals' design and production of teaching aids and classroom records as well as the scores given by teachers of different subject matters. All class observations and student activities were conducted during the fall semester of the 2010 academic year.

\section{Research design}

This study employed an action research approach, with the instructor's blog and the blogs for the study groups aimed at facilitating interactions and teaching. Blogs also served to collect information about the teaching process. All qualitative data including the students' blogs, teacher's observations and reflections, and students' discussions and feedback were collected and analysed through content analysis technique. Responses to the learning attitude survey were analysed statistically using SPSS.

\section{Research tools}

The following research tools were used in this study:

1. Blogs: Wretch of Yahoo was used with options including posts of pictures and articles, replies, and messages (Figure 1).

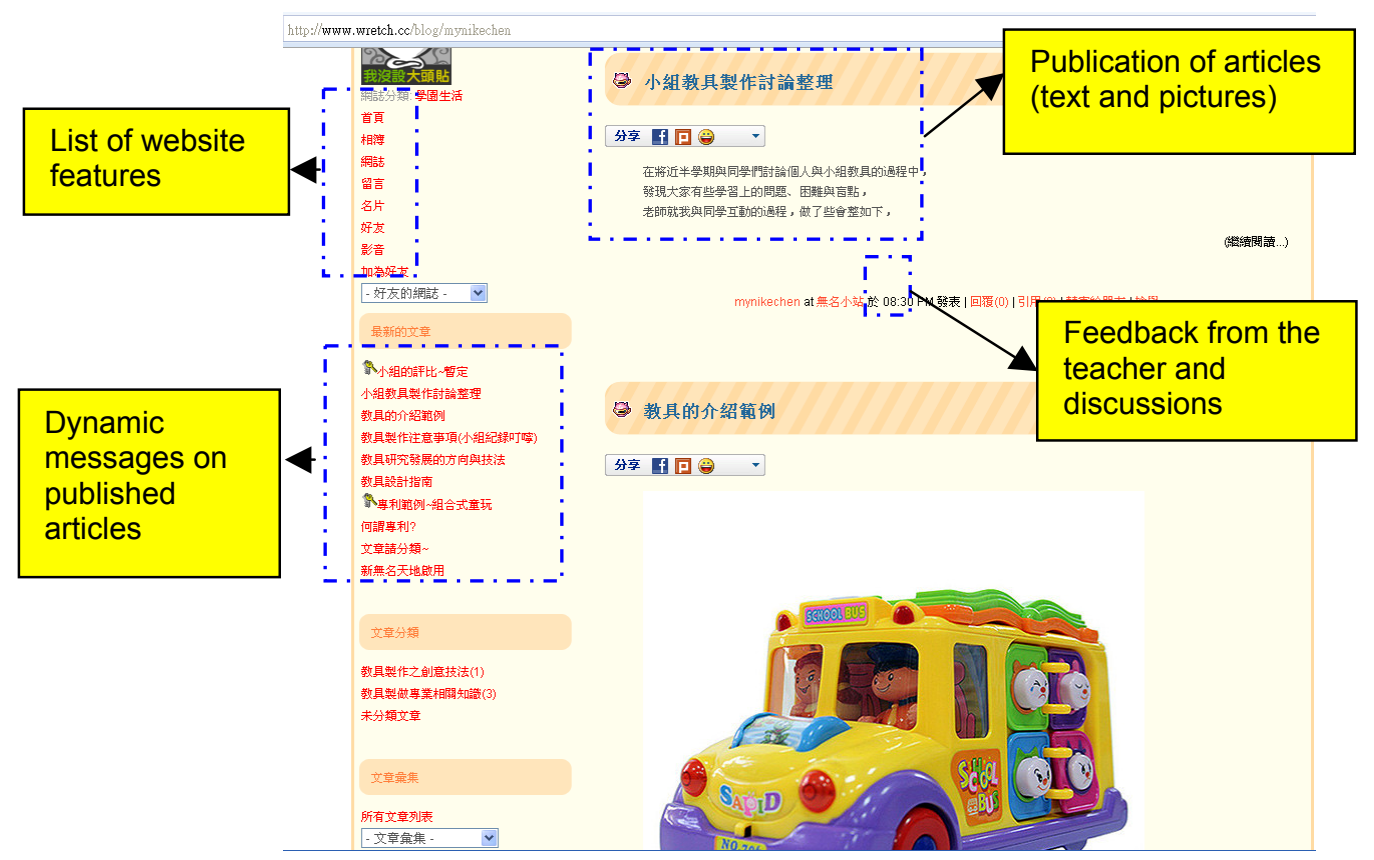

Figure 1: A blog as a teaching platform

2. Learning effectiveness evaluation: The evaluation was based on theoretical foundations and aimed to assess learning effectiveness, including the instructor's teaching aid worksheet and the number of the teaching aids qualified to apply for patents. 
3. Learning attitude survey: The survey contains five domains including learning effect, learning attitude, actual behaviour, cooperative learning, and use of blogs in blended creative teaching along with the semi-structured student logs, work briefs, and reports.

All activities employed in this study were conducted in Chinese and translations into English were made by the authors.

\section{Teaching design concepts}

Figure 2 illustrates the teaching design concept in this study according to the research purposes and procedures.

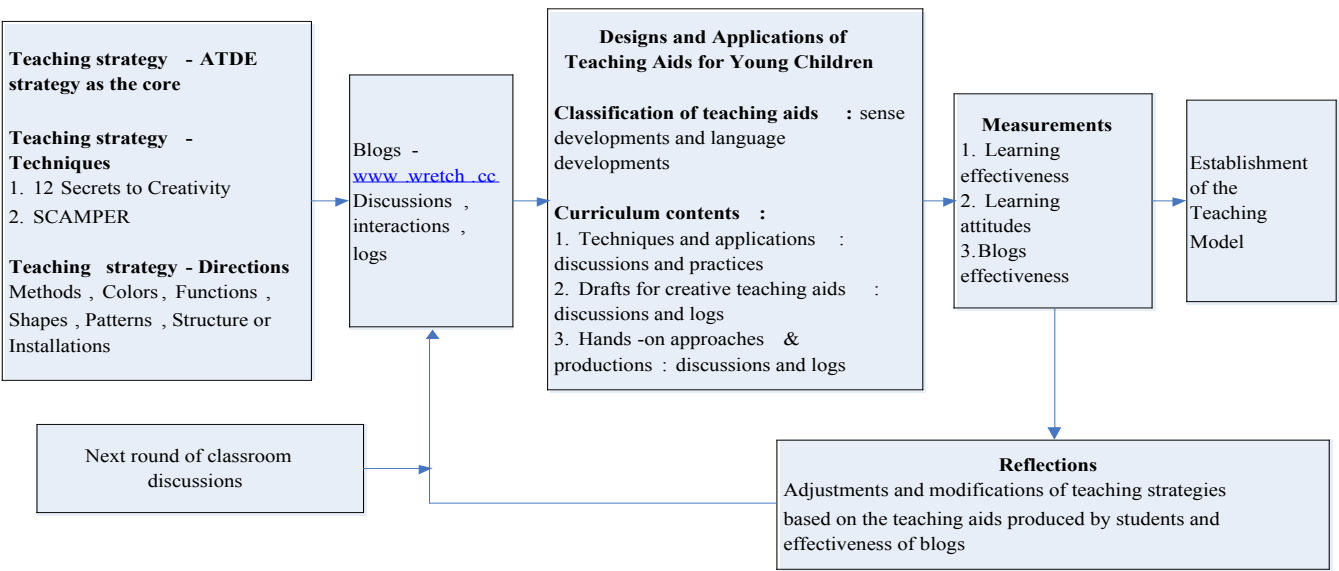

Figure 2: Concept of blended creative teaching design

\section{Results and discussion}

\section{Blended creative teaching}

Blended creative teaching model

This study combined face to face teaching in classrooms and blog learning activities. In addition to the classroom activities, teachers and students could discuss and share their thoughts using blogs. Teachers validated the knowledge, experience, and background of students in activities and incorporated the creative teaching strategy as a guide for both teaching and learning. The blended creative teaching model (Figure 3) described in this paper was applied over a period of 12 weeks, divided into six stages, namely preparation, 'testing the water', teaching adjustments, teaching confirmation, teaching integration, and extension and development. The extension and development stage determined whether further development was required based on the results. Three classes per week (two classroom hours, one online hour) were recommended.

The face to face and blog learning activities were alternated and designed according to the curriculum requirements. Face to face classes covered blog operations, writing skills for learning logs, establishment of professional knowledge, improvement of data collection ability, introduction to creative teaching techniques, and progress confirmation. Overall, the focus of the face to face activities was to build students' 
basic knowledge regarding the production of teaching aids for young children and IT literature, so that students could quickly focus on the learning objectives. Blog learning was done both in the study groups and individually. Because of the flexible nature of the technology, learning continued without any restrictions on time or space with regard to data collection, questions, feedback, observations and sharing.

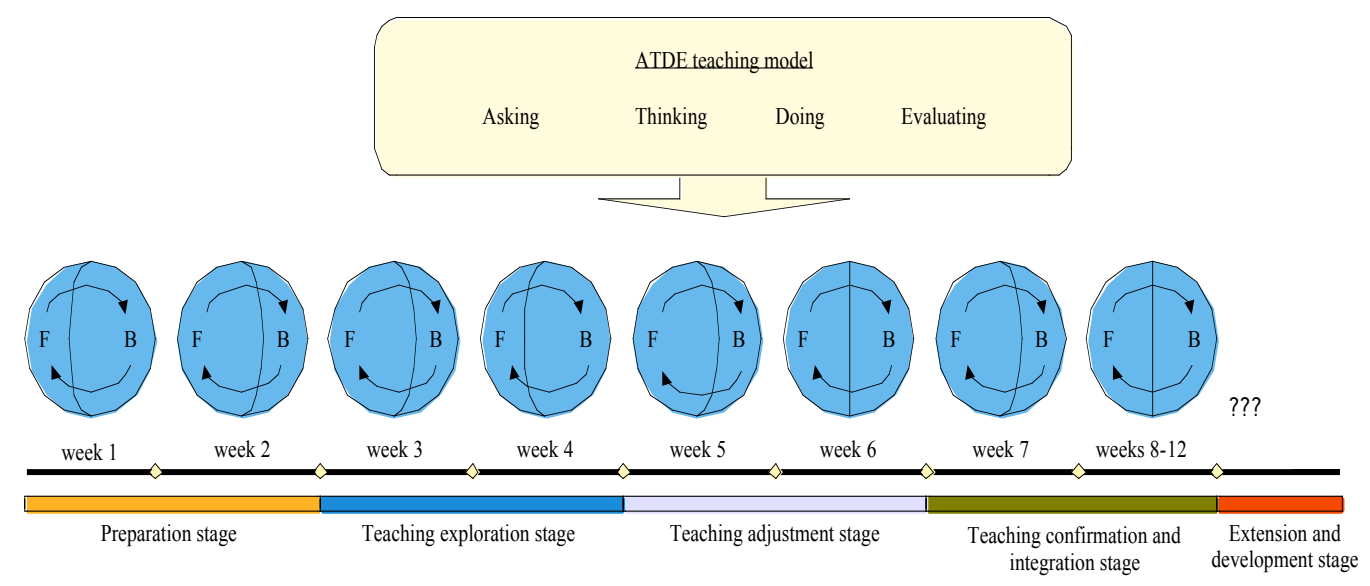

Figure 3: Blended creative teaching model

Examples of creativity

This study applied the blended creative teaching model to learning activities in the course Design and Production of Teaching Aids for Young Children. Learning effectiveness was apparent in the cooperative learning, the hands-on experiences and the alternation between face to face teaching and online interactions. In addition to the establishment of professional knowledge, students quickly accumulated experience by observing of a large number of works. However, appropriate guidance from teachers was required so that the students did not simply imitate what they saw. At the outset of the activities, students gathered a significant amount of information and observed off-the-shelf teaching aids as a start to their creative thinking. They completed their work via discussions, hands-on production, and design modifications focusing on the operability of users.

One example of the creative teaching aids is Big Mouth, which uses the off-the-shelf teaching aid Croc Dentist. At the beginning, students focused on the improvement of functions.

1. If you plug away a healthy tooth by mistake, Mr Croc will cry immediately!

2. If you plug away too many healthy teeth, Mr Croc will flap his two feet.

3. This game comes with additional erasable black ink (to spray on teeth to create tooth decays) and a toothbrush that can easily remove the black ink on teeth.

After multiple discussions, students expanded their thinking. They thought beyond the technical aspects and developed practical and creative teaching aids with feasible materials and methods (Table 3). A brief overview of the development of the new teaching aids is as follows: 
Table 3: Summary of the teaching aid characteristics

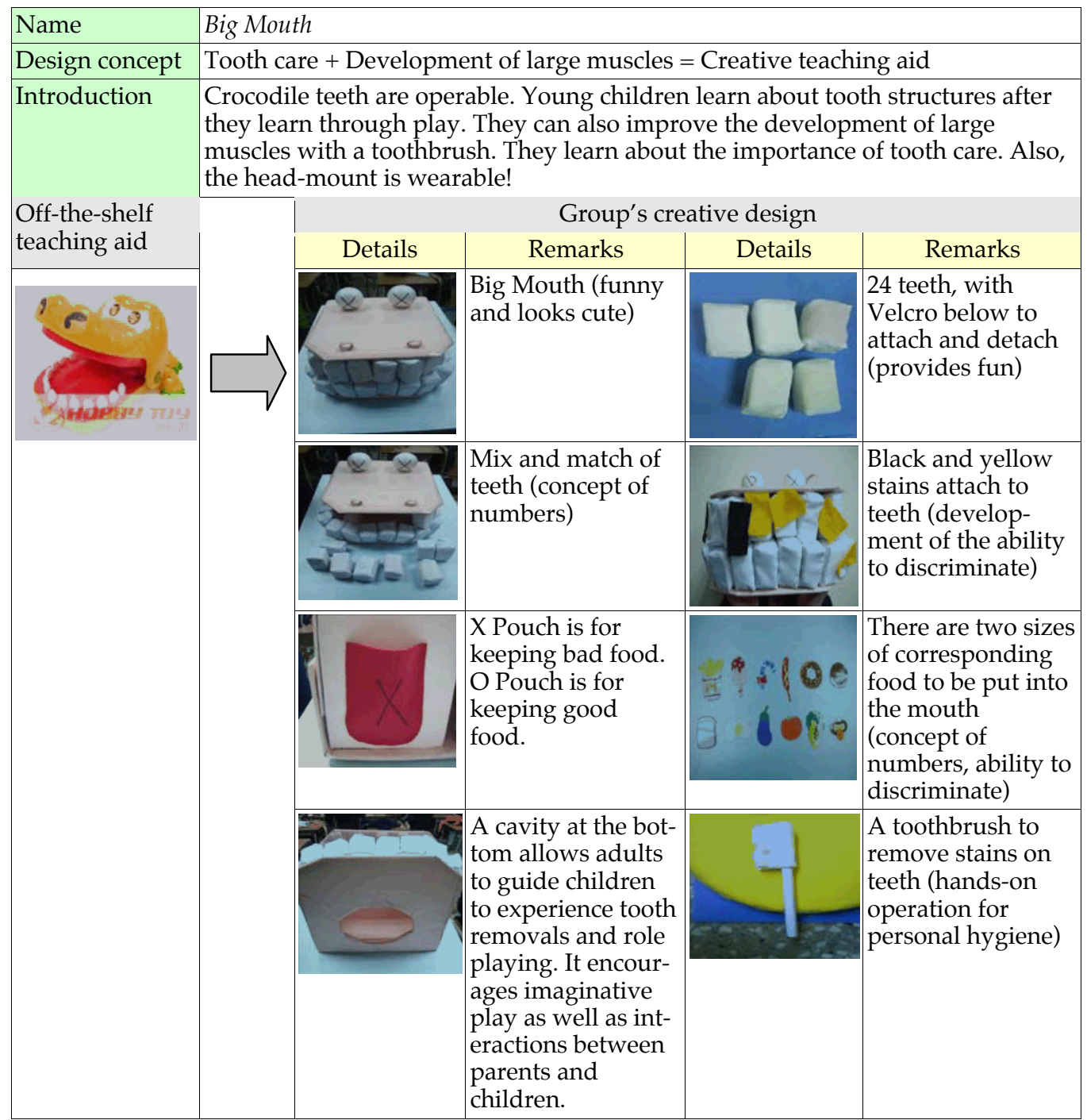

1. This original concept teaches young children to distinguish healthy and decayed teeth, and allows them to enjoy the fun of plugging, and brushing teeth while watching the crocodile's different responses. The attached ink can change the status of teeth.

2. A few discussions between the teacher and students concluded that it was not possible to make the crocodile cry or flip its feet. Further, there was no knowledge of how the special ink is made.

3. A decision was made to make a crocodile mouth that can be opened with a zipper in order to teach to young children how to take care of teeth. Further, it was decided to produce a head-mount for a crocodile with a mouth that could actually open. This teaching aid aimed to allow young children to have fun brushing teeth and plugging teeth. There are 10 teeth on the upper level and 10 teeth on the lower 
level. There is also good food and bad food. A little pouch on the upper jaw collects bacteria.

4. The team noticed that it was difficult to make the head-mount open and close easily. In addition, the food pictures were too small, teeth could fall off too readily, and it was hard to operate the pouch if it was on the upper jaw. Re-adjustments were made to fix these problems.

\section{Learning effectiveness under blended creative teaching}

Below are the evaluations of learning effectiveness under the blended creative teaching model, based on the assessment of teachers in accordance with "12 Secrets to Creativity," SCAMPER, patenting techniques, and the patent applications of teaching aids.

\section{"12 Secrets to Creativity" and SCAMPER}

Table 4 summarises the applications of "12 Secrets to Creativity" and SCAMPER in the deveopment of teaching aids by different study groups according to the implications of creative teaching.

Table 4: Application of "12 secrets to creativity" and SCAMPER

\begin{tabular}{|c|c|c|c|}
\hline & 12 Secrets to Creativity & SCAMPER & Applications on teaching aids \\
\hline 1. & $\begin{array}{l}\text { Addition, augmentation and } \\
\text { increase }\end{array}$ & $\begin{array}{l}\text { 1. Combin- } \\
\text { ation }\end{array}$ & $\begin{array}{l}\text { Chu-Mi Robot, Teddy Bear Massager, Happy } \\
\text { Fruit Orchid, Creative Puppet Show Group, } \\
\text { Butterfly Backpack, Water Bottle at Work, } \\
\text { Animal Train, Recycling Mini-Truck, Happy } \\
\text { Bus }\end{array}$ \\
\hline 2. & $\begin{array}{l}\text { Elimination and reduction } \\
\text { (deduct something) }\end{array}$ & 2. Elimination & \\
\hline 3. & $\begin{array}{l}\text { Expansion and extension } \\
\text { (expand something) }\end{array}$ & & $\begin{array}{l}\text { Big Mouth, Happy Fruit Orchid, Butterfly } \\
\text { Backpack, Happy Bus }\end{array}$ \\
\hline 4. & $\begin{array}{l}\text { Compression (compress } \\
\text { something) }\end{array}$ & & $\begin{array}{l}\text { Happy Fruit Orchid, Yi La Hu, Recycling } \\
\text { Mini-Truck }\end{array}$ \\
\hline 5. & $\begin{array}{l}\text { Improvement (change } \\
\text { something) }\end{array}$ & 3. Adjustment & $\begin{array}{l}\text { Big Mouth, Teddy Bear Massager, Creative } \\
\text { Puppet Show Group, Water Bottle at Work }\end{array}$ \\
\hline 6. & $\begin{array}{l}\text { Alternation and } \\
\text { rearrangements (alter } \\
\text { something) }\end{array}$ & $\begin{array}{l}\text { 4. Rearrange- } \\
\text { ment }\end{array}$ & $\begin{array}{l}\text { Chu-Mi Robot, Happy Fruit Orchid, Butterfly } \\
\text { Backpack, Water Bottle at Work, Animal Train }\end{array}$ \\
\hline 7. & $\begin{array}{l}\text { Movement and push-around } \\
\text { (move something) }\end{array}$ & & Chu-Mi Robot, Animal Train \\
\hline 8. & $\begin{array}{l}\text { Imitation (learning } \\
\text { something) }\end{array}$ & & $\begin{array}{l}\text { Big Mouth, Chu-Mi Robot, Teddy Bear } \\
\text { Massager, Yi La Hu, Butterfly Backpack, } \\
\text { Recycling Mini-Truck }\end{array}$ \\
\hline 9. & $\begin{array}{l}\text { Replacement (replace } \\
\text { something) }\end{array}$ & 5. Replacement & Creative Puppet Show Group, Happy Bus \\
\hline 10. & Connection (link something) & & $\begin{array}{l}\text { Big Mouth, Chu-Mi Robot, Teddy Bear } \\
\text { Massager, Butterfly Backpack, Animal Train }\end{array}$ \\
\hline 11. & $\begin{array}{l}\text { Reversals (reverse } \\
\text { something) }\end{array}$ & 6. Utilisation & \\
\hline 12. & $\begin{array}{l}\text { Regulations and boundaries } \\
\text { (define something) }\end{array}$ & & $\begin{array}{l}\text { Chu-Mi Robot, Teddy Bear Massager, } \\
\text { Creative Puppet Show Group, Yi La Hu, } \\
\text { Butterfly Backpack }\end{array}$ \\
\hline
\end{tabular}


Table 4 shows that the most frequently used techniques are additions, augmentations, increases, and imitations. Eliminations and reversals were not used.

Patenting techniques and results of patent applications

Patents can be obtained through innovations and developments in six directions (Chou, 2008). Patent applications require three elements: novelty, inventive steps, and non-obviousness (industry applications). Table 5 summarises the application of six patenting techniques in the production of teaching aids.

Table 5 shows that the most common techniques applied were methods, functions, structures, and installations, followed by shapes. As the ultimate purpose of the design and production of teaching aids was to serve young children, patterns, and color were considered to be of less critical importance. In terms of patent applications, Big Mouth, Chu-Mi Robot, Teddy Bear Massagers, Butterfly Backpack, and Water Bottle for Work were reviewed by the experts. Afterwards, Big Mouth, Teddy Bear Massager, and Butterfly Backpack were recommended to apply for patent applications, with the first two as new inventions and the third as a new utility. This means $60 \%$ of the created teaching aids were qualified for patent reviews.

\section{Summary of feedback from experts/teachers}

This study obtained feedback from seven experts including three teachers with more than five years experience in kindergartens, two teachers with more than 23 years experience in kindergartens (including one also serving as a part-time teacher in the department of early children education in a vocational school) and two full-time teachers in the department of early children education with seven years of experience. A summary of their feedback is listed below.

1. Creativity and novelty of teaching aids: All the seven experts/teachers were impressed with the novel looks, uniqueness and diversity of functions of these teaching aids.

2. Details in sewing work of teaching aids: Details such as turns and connections of clothes in the teaching aids were well considered.

3. Practicality of teaching aids: These teaching aids offered appropriate operational methods for the target audience.

4. Attractiveness of the looks: Chu-Min Robot, Teddy Bear Massagers, Mr. Croc, Butterfly Backpacker and Recycling Mini-Truck were very appealing to young children.

\section{Attitudes and performances}

In order to gauge the learning attitudes of students under blended creative teaching, a learning feedback survey and feedback records were analysed as follows.

\section{Learning attitude measurement}

According to the survey of learning feedback from students, most of their parents graduated from high schools or vocational schools and currently work in industries or businesses. The majority of students leave messages on the blogs of their own study groups twice per week and on the blogs of other groups once per week. Most of the messages to their own groups are about the learning from group discussions, followed by mutual encouragement and support. Most of the messages to other groups are regarding mutual encouragement and support, followed by the updating of teaching aid production status and sharing of problems and difficulties. There are five performance elements in learning about the production of teaching aids: learning 
Table 5: Application of patenting techniques in production of teaching aids

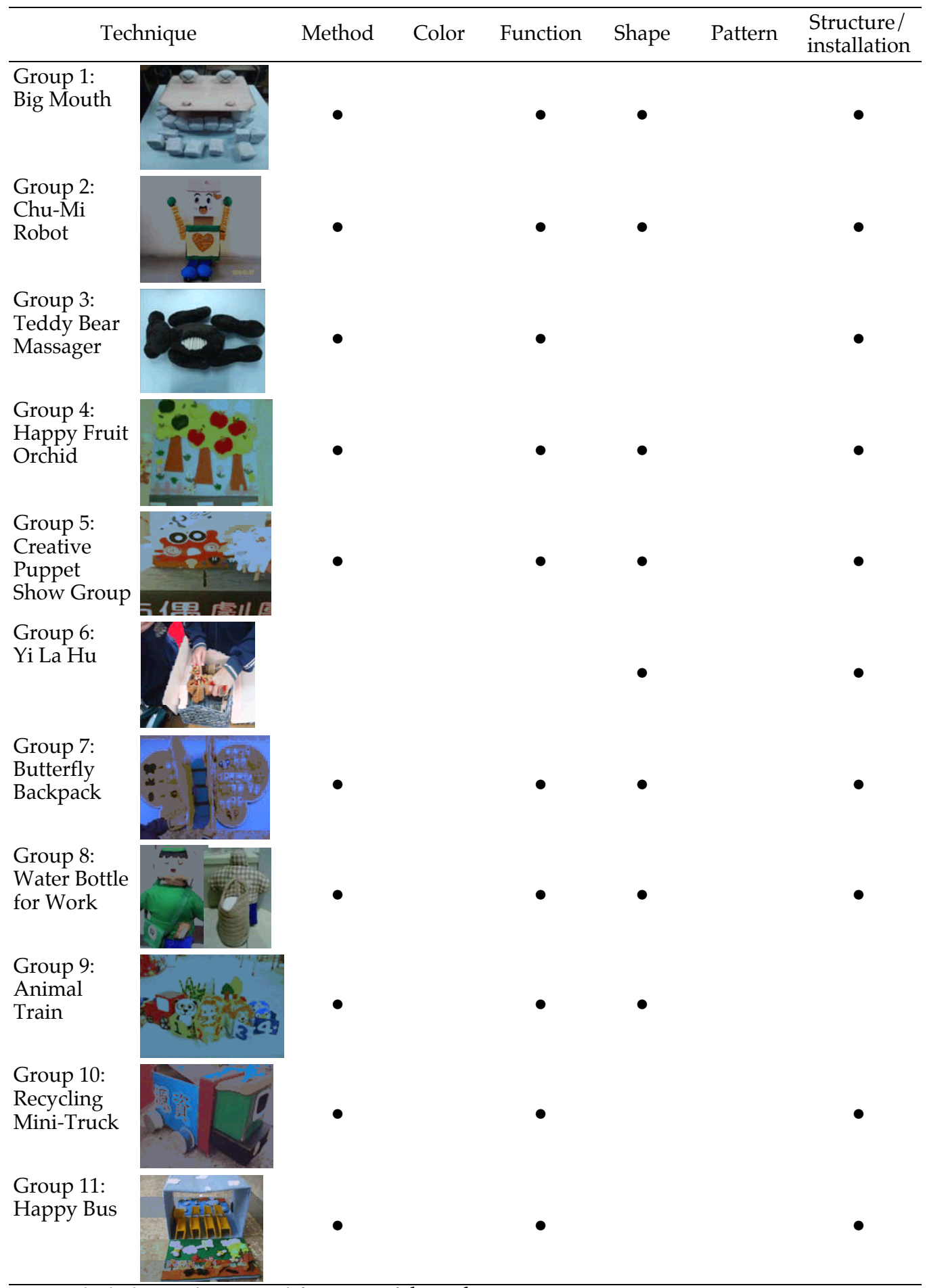

Note: Black dots indicate modifications of the techniques. 
effectiveness, learning attitude, behaviour, cooperation, and blog usages. All items in learning effectiveness show significant results other than two items, "I find it difficult to learn under blended creative teaching" and "The task allocations are fair." This means that students do not find learning under blended creative teaching to be difficult, and the task allocations are considered unfair.

Learning feedback

Below is the analysis of the learning feedback from the students. The purpose is to understand the learning implications for blended creative teaching (Codes: The first digit means the group number. The second digit refers to the student. The third digit refers to the question number. For example, 2-S1-1 means the first student in the second group answering the first question).

1. Learn by doing. Students all acknowledge their growth and the expansion of their professional knowledge and skills in teaching aid productions. This growth results from the actual doing and thinking throughout the process. Meanwhile, this also transforms students from a state of passiveness to one of active participation. They have to collect data while enriching their own knowledge and understanding. They learn to be creative in the application and combination of materials. They build up a solid foundation of professional skills and creative thinking by finding solutions to overcome difficulties.

2-S1-1: My biggest learning area is how to overcome difficulties and find the right way to produce the teaching aid. I also tried many new things in this experience. I feel great about it.

3-S2-1: We visited many places to look for materials. We learned a lot more about baby care products. We also found many new things. We did not know that we could spend a whole morning in the shop. We encountered many problems in the production of Teddy Bear. At the beginning, we enlarged the paper template due to the sign of the touch ball. We also removed the wooden stick we originally wanted to place on the top of the Teddy Bear's head. There were also difficulties in the belly, wheel and sawing. We eventually overcame all the problems. I learned to try other ways first instead of asking for help. The problem-solving gave me the greatest sense of achievement.

In summary, the hands-on experience allows students to train their skills as they participate in trial-and-error situations, learn to analyse and compare, solve problems, summarise findings and operate as a team. In the end, they express what they learned in their works.

2. Support from teachers. Support from teachers is critical in blended creative teaching. It strengthens the professional competences of students, allows students to focus quickly and provides them with multiple-facet concepts.

4-S2-1: I was a novice at the production of teaching aids. I was also clueless to the writing of learning logs. We only had a better idea after the teacher provided an explanation. We then realised that the writing of learning logs is actually rather straightforward.

8-S1-1: We ask the teacher whenever we have problems. We discuss and brainstorm together. Sometimes we have different ideas. The teacher will patiently explain things to us so that we can understand [Water Bottle at Work]. 
3. Importance of team work. Study groups offer an opportunity for students to work cooperatively. This differs from the previously used individualistic approach. The sharing of different opinions helps student to reflect on their own experience and foster team spirit. It also generates creative spark (Liaw, Chen \& Huang, 2008).

1-S3-1: Team work! This is the most valuable experience during the past few weeks. One or two persons alone cannot do the job well. Three brains are better than one. Although our work fell below our expectations, we learned a valuable lesson from our mistake. This was the first time we worked as a team to make teaching materials.

5-S4-1: This is the first time we made teaching materials in a study group. I learned that everybody has different ideas and we need to respect others' thoughts. I learned how to do things differently from this experience.

Study groups test the friendship, communication, organisation, and work allocations among peers. Good chemistry, mutual support, and a sense of responsibilities and efforts indeed improve performance. Students learn a lot about task assignments and workload sharing. This is another important issue for the teacher, in addition to the instruction on professional knowledge and skills.

4. Interactions between group members. This study used blogs as the platform for blended teaching. This approach places no limitations on time or space. This easyto-operate platform facilitates the sharing of information and knowledge and promotes the interaction between teachers and students, as well as between classmates. It is a positive development for both teachers and students (Du \& Wagner 2007; Dippold, 2009).

3-S2-3: I learn from reading other groups' papers. You only grow by learning the strengths of others. I pay attention to the teaching materials designed by others. The posting of messages and responses allows me to understand better the pros and cons of my own design. We accept the feedback from others and make constructive suggestions.

9-S2-3: Blogs allow us to learn from other groups by observing their teaching materials and task assignments. Blogs improve our communication within the same group. We can solve problems together by listening to the feedback from others.

4-S1-3: All the content is posted onto the blog and the teacher keeps giving us feedback. We can make modifications based on the teacher's feedback. We can also understand what other groups are doing. It is a good way of learning from each other.

9-S4-3: We can discuss with the teacher using the blog and make improvements based on the feedback from the teacher and other groups. Blogs are a great communication channel!

According to the results discussed above, the blended creative teaching model incorporated with ATDE was modified and improved. An ideal blended creative ATDE teaching model should be implemented for 12 weeks and properly incorporated with strategies of the "12 Secrets to Creativity" and SCAMPER. In doing so, the ideal teaching model can be effectively and continuously administered to the Design and Production of Teaching Aids course in the following academic years.

\section{Conclusions}

An ideal blended creative teaching model incorporated with ATDE was developed in this study and was subsequently approved. It is recommended to be employed three 
hours a week for three months (12 weeks) and should include two hours of professional knowledge, skills, question discussions, and progress confirmation as well as one hour of computer instruction in blog application, presentation teaching, or Internet data searching. In addition, the whole class can be divided into six stages, including preparation, testing the water, teaching adjustments, teaching confirmation, teaching integration, and extension and development. Each stage of teaching should last two weeks. Meanwhile, the ATDE teaching model, patenting techniques, "12 Secrets to Creativity," and SCAMPER were successfully adopted as creative teaching strategies. The teaching experience captured in this study shows that the creative teaching strategy provides a feasible teaching framework and helps students improve their performance in the production of teaching aids. Patenting skills include methods, functions, structures and installations. SCAMPER and "12 Secrets to Creativity" can be used as guides for making improvements. Furthermore, the results indicate that students' interaction and collaboration can improve through this blended teaching and learning approach (Lou at al, 2010; Shih, 2010; Wang, 2010). As a result, this blended creative teaching model was implemented in the following academic year.

Finally, the work, attitude measurements, and feedback from students all indicate that blended creative teaching helped them complete their creative works. Students were able to interact, communicate, reflect, and learn from each other in a dynamic, supportive and peer assisted learning environment (Tan, Ladyshewsky \& Gardner, 2010). Their works are innovative, practical and sophisticated. Most of the items in the performance review show favourable feedback, which indicate that blended creative teaching created positive outcomes in learning effectiveness, attitudes, willingness to cooperate and the use of blogs. Blended creative teaching is also beneficial to the acquisition of professional knowledge and skill sets. It also improves interactions between teachers and classmates as well as the communication, problem solving and writing skills of students.

\section{Suggestions}

The study shows that blended creative teaching is feasible for teaching the Design and Production of Teaching Aids course. Because blogs have advantages such as removing the restrictions of time and space and enriching the teaching content, they are recommended for use in similar practical curricula such as teaching aid production, product designs and development and special productions. Whilst the results of the attitude survey were favourable, there are still problems associated with uneven allocations of workload. Therefore, teachers are advised to specify the ground rules for task allocation so that study group members know their responsibilities. The process of group learning should also be observed so that teachers can make necessary adjustments and suggestions, thus enabling students to utilise their own skills and achieve their common learning goals. Because this study investigated only the students in the department of early childhood education in a vocational school in Pingtung City, the results are limited and cannot be generalised. Follow-up studies could expand the scope in order to understand the differences with students in different contexts and locations. As learning status is subject to the influence of teachers, peers and environment, future studies should examine the methods by which teachers guide students, the interactive models between learners, work by individuals or groups, differences between homogenous and heterogeneous groups, and comparing outcomes from blended creative teaching and traditional teaching. 


\section{References}

Bersin, J. (2004). The blended learning book: Best practices, proven methodologies, and lessons learned. San Francisco, CA: Pfeiffer.

Brady, M. (2005). Blogging: Personal participation in public knowledge building on the web. Chimera Working Paper Number: 2005, 02. [verified 19 May 2012]

http: / / recepzihni.org /..2010=fall=MANAGEMENT.INFORMATION.SYSTEMS / Knowledge Society / 15949059-CWP-2005-02-Blogging-in-the-Knowledge-Society-MB.pdf

Chen, L. A. (2002). Design and implementation of creativity training courses. The International Conference for Creativity Course Development 2002, pp. 185-214. Taipei: National Taipei Teachers' College.

Chen, S. Y. (2004). Web-based teaching activities in pre-service teacher education courses. Curriculum \& Instruction Quarterly, 7(1), 123-138.

Chen, Y. L., Liu, E. Z. F., Shih, R. C., Wu, C. T. \& Yuan, S. M. (2011). Use of peer feedback to enhance elementary students' writing through blogging. British Journal of Educational Technology, 42(1), E1-E4. http:/ / dx.doi.org/10.1111/j.1467-8535.2010.01139.x

Dippold, D. (2009). Peer feedback through blogs: Student and teacher perceptions in an advanced German class. ReCALL, 21, 18-36. http: / / dx.doi.org/10.1017/S095834400900010X

Du, H. S. \& Wagner, C. (2007). Learning with weblogs: Enhancing cognitive and social knowledge construction. IEEE Transactions on Professional Communication, 50(4), 1-16. http: / / dx.doi.org/10.1109/ TPC.2006.890848

Jou, J. M. (2008). Originality thinking training (2nd ed.). Taipei: Chuan Hwa.

Khine, M. S. (2007). Teaching with technology: Strategies for engaging learners (M. H. Wang, trans). Taipei: Pearson Education Taiwan.

Kuo, Y. Y. (1994). Skills of creative problem solving. Taipei: Psychological Publishing.

Ko, C. E. (2004). Application of creative thinking model based on metacognitive theory in teaching. Curriculum \& Instruction Quarterly, 7(1), 15-30.

Liaw, S. S., Chen, G. D. \& Huang, H. M. (2008). Users' attitudes toward Web-based collaborative learning systems for knowledge management. Computers $\mathcal{E}$ Education, 50, 950-961. http: / / dx.doi.org/10.1016/j.compedu.2006.09.007

Lin, W. W. (2002). The relationship among organizational cultures, teachers' potentials for teaching creativity, and creativity teaching. Unpublished doctoral dissertation, National Chengchi University, Taipei, Taiwan.

Liu, C. C. (2005). The effect of blog characteristics on the trust of blog. Unpublished Masters dissertation, National Taiwan University of Science and Technology, Taipei, Taiwan.

Liu, E. Z. F. \& Chang, Y. F. (2010). Gender differences in usage, satisfaction, self-efficacy, and performance of blogging. British Journal of Educational Technology, 41(3), E39-E43. http: / / dx.doi.org/10.1111/j.1467-8535.2009.00939.x

Lou, S. J., Wu, S. C., Shih, R. C. \& Tseng, K. H. (2010). Adoption of blogging by a Chinese language composition class in a vocational high school in Taiwan. Australasian Journal of Educational Technology, 26(6), 898-916. http: / / www.ascilite.org.au/ajet/ ajet26/lou.html

Ozkan, Y. (2011). Blogging in a teaching skills course for pre-service teachers of English as a second language. Australasian Journal of Educational Technology, 27(4), 655-670. http: / / www.ascilite.org.au/ajet/ajet27/ozkan.html

Shen, J. H. (2007). The application of blog in elementary school. Unpublished Masters thesis. National University of Tainan, Tainan, Taiwan.

Shih, C. L. (2005). Interpreting global wave of blog. Business Next, 108-56-63. 
Singh, H. (2003). Building effective blended learning programs. Educational Technology, 43(6), 5154.

Shih, R. C. (2010). Blended learning using video-based blogs: Public speaking for English as a second language students. Australasian Journal of Educational Technology, 26(6), 883-897. http:/ / www.ascilite.org.au/ajet/ajet26/shih.html

Shih, R. C. (2011). Can Web 2.0 technology assist college students in learning English writing? Integrating Facebook and peer assessment with blended learning. In J. Waycott \& J. Sheard (Eds), Assessing students' Web 2.0 activities in higher education. Australasian Journal of Educational Technology, 27(Special issue, 5), 829-845. http:/ / www.ascilite.org.au/ajet/ajet27/shih.html

Taiwan Elementary and Secondary Educator Community (TESEC) (2008). The outline of the nineyear compulsory curriculum. [in Chinese] http:/ / teach.eje.edu.tw/9CC2/9cc_97.php

Tan, S. M., Ladyshewsky, R. K. \& Gardner, P. (2010). Using blogging to promote clinical reasoning and metacognition in undergraduate physiotherapy fieldwork programs. Australasian Journal of Educational Technology, 26(3), 355-368. http: / / www.ascilite.org.au/ajet/ajet26/tan.html

Wang, H. S. \& Su, S. T. (2005). The key factors of implementing blended digital learning for inservice teachers. Journal of Secondary Education, 14, 219-250.

Wang, M. J. (2010). Online collaboration and offline interaction between students using asynchronous tools in blended learning. Australasian Journal of Educational Technology, 26(6), 830-846. http: / / www.ascilite.org.au / ajet/ ajet26/ wang.html

Wu, C. S. (2003). Knowledge economy and educational development. Taipei: Shtabook.

Yu, C. P. (2008). Blenden Learning im DaF-Unterricht Moglichkeiten und Schwierigkeiten - Ein Beispiel im Audio-Visuellen Unterricht. Unpublished Master dissertations, National Kaohsiung First University of Science and Technology, Kaohsiung, Taiwan.

Yan, X. L., Lou, S. J. \& Wang, Y. Y. (2009). The advantages of incorporating blended learning into situational composition for vocational high school students. 2009 Globalization, Industrial Change, and Development of Technical and Vocational Education Conference. Pingtung County.

Authors: Professor Shi-Jer Lou, Graduate Institute of Technological and Vocational Education, National Pingtung University of Science and Technology, Taiwan.

Email: lou@npust.edu.tw

Nai-Ci Chen, Senior High School Teacher, Pingtung County Ping Rong High School, Taiwan.

Huei-Yin Tsai, Doctoral student, Department of Industrial Technology Education, National Kaohsiung Normal University, Taiwan.

Professor Kuo-Hung Tseng, Graduate Institute of Business and Management, Meiho University, Taiwan.

Ru-Chu Shih (corresponding author), Associate Professor of Modern Languages, National Pingtung University of Science and Technology, Taiwan. Email: vincent@npust.edu.tw

Please cite as: Lou, S. J., Chen, N. C., Tsai, H. Y., Tseng, K. H. \& Shih, R. C. (2012). Using blended creative teaching: Improving a teacher education course on designing materials for young children. Australasian Journal of Educational Technology, 28(5), 776792. http:/ / www.ascilite.org.au/ajet/ ajet28/lou.html 